\title{
Assessment of the Petrochemical Industry Pollution on the Skikda Bay, Algeria
}

\author{
Boutefnouchet Nafissa $^{1 *}$, Noureddine Bouzerna ${ }^{1}$ and Houria Chettibi ${ }^{1}$ \\ ${ }^{1}$ Faculté des Sciences, Département de Biochimie, Université Badji Mokhtar, B.P. 12, El-Hadjar, Annaba (23200), Algeria \\ *Correspondence to Pr. Boutefnouchet Nafissa. Email: boutefnaf@yahoo.fr
}

Received: 13 October 2005 / Accepted: 23 February 2005 / Published: 30 December 2005

\begin{abstract}
The Skikda bay is located in the northern part of Algeria. The area is in contact with a petrochemical industrial complex, which raw materials and final products contaminate the surrounding areas via atmospheric pollution as well as effluents, which are dumped into seawaters. To establish the effects of these pollutants and waste disposal on the vicinity of the bay, several samples were taken at different distances along the bay and the outfall pipes of the industrial complex. Subsequently, several chemical analyses were made to analyze the concentrations of hydrocarbons, $\mathrm{CO}_{2}, \mathrm{Ca}^{+2}$ and $\mathrm{Mg}^{+2}$, chlorides and phosphates and the alkalinity present into the samples. Several concentrations of the above constituents are reported as a function of the different sites.
\end{abstract}

Keywords: Hydrocarbons, pollutions, Skikda bay.

\section{Introduction}

Its marvellous beaches along the north-eastern part of Algeria characterize Skikda province. However, beside these marvellous beaches a huge petrochemical industry plant was built about three decades ago and has become one of the largest refineries in the world. The petrochemical complex of Skikda, from which toxic waste generation is inherent to its usual activities and processes, is located at the border of an important bathing area to which several thousands people travel. Due to the recent and rigorous environment regulation imposed by the international community on environment, industrial activities shall be strictly controlled [1].

This paper reports on the influences of industrial pollution on the properties of soils and its impact on the marine environment, which could harm the fish and pollute the neighbouring bathing resorts. The objectives of this study are to determine the effects of hydrocarbons and other constituents in the waste dumping on each other and their variations along the studied sites with different distances from the petrochemical plant $[2,3]$. The study also shows the important concentrations of different chemical constituents found in the dumping area and therefore, helps for a better understanding of the contamination process and consequently will push the decision making authority to plan for a corrective actions if necessary in the future.

\section{Materials and Methods}

\section{Sampling}

Sampling sites extended along six locations close to the refinery of Skikda bay in the north eastern part of Algeria (figure 1.a-c), whereas other major sampling were concentrated on the effluents of the refinery unit in different points, that is samples have been taken from different creeks that have a direct access to seawater and to the creek downstream soil (figure 2). The liquid samples were stored in bottles, the sample volumes were about $250 \mathrm{~cm}^{3}$ to $500 \mathrm{~cm}^{3}$ for each bottle. The solid samples were collected by raking with a spatula or a rake then transported into small containers covered with aluminium paper. Each container weighs about $100 \mathrm{~g}$, the sampling temperatures were taken with a standard thermometer were measured to be $26^{\circ} \mathrm{C}$ and $28^{\circ} \mathrm{C}$ depending on the site location as indicated in Table 1.

\section{Samples Conservation}

The samples were transported into containers under low temperatures $\left(4^{\circ} \mathrm{C}\right)$ in order to avoid the photo oxidation phenomena of the organic substance contained in these samples from one hand and to avoid the micro flora multiplication from another hand. The chemical analyses are carried out immediately after sampling. Several chemical methods analyses have been performed at the Skikda refinery laboratory in order to know the constituency of these samples. These methods are presented in the subsequent sections. 

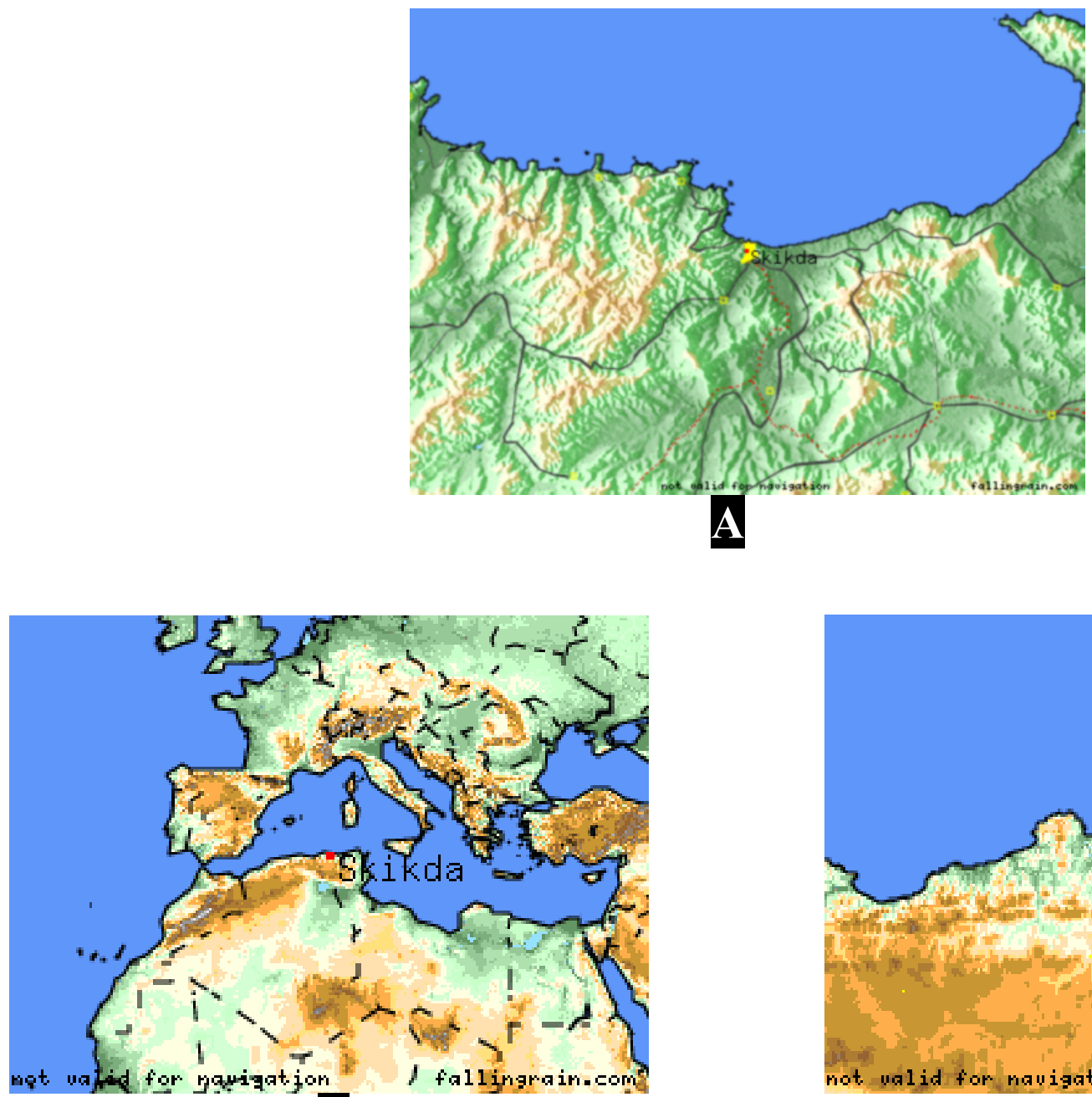

B

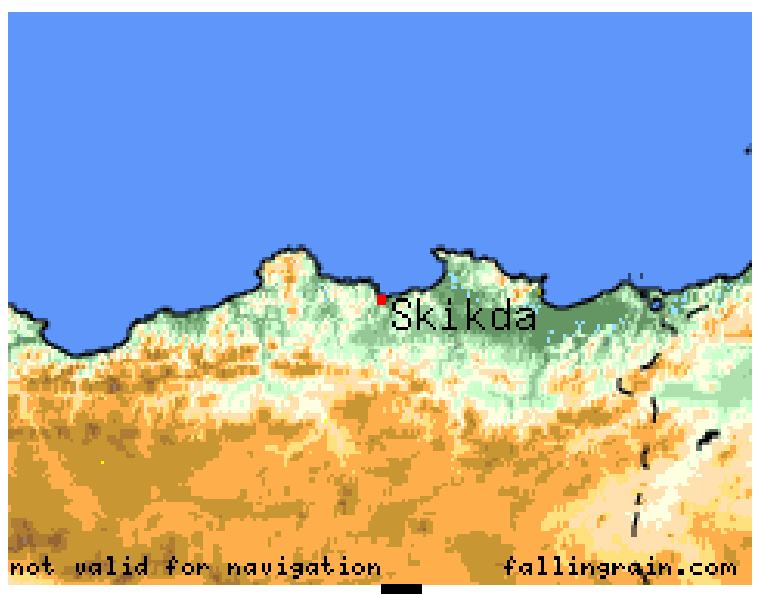

Figure 1: The study area (A-C): Skikda bay area with different zooming.

\section{2-Skikda port}

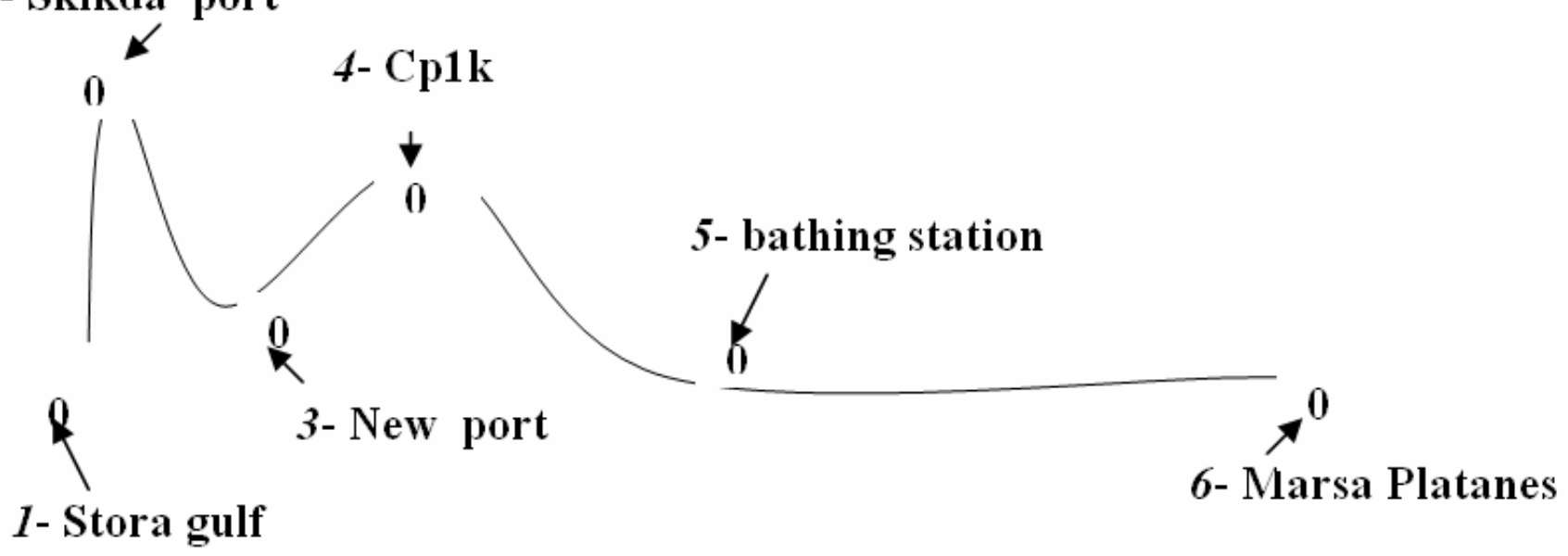

Figure 2: Studied Littoral zone of Skikda bay(Algeria): 1-Fishing port located at the Stora gulf, 2-Ancient port located in the center of the town, 3-New port located at the entry of the industrial zone, 4-Effluents dumping from the Cp1k (Petrochemical complex of Skikda), 5-Bathing station post 7 Larbi Ben Mhidi, 6-The Platanes Marsa. 
Table 1: Different chemical constituents expressed in ppm and corresponding to six different sampling points.

\begin{tabular}{lccccccc}
\hline Site & 1 & 2 & 3 & 4 & 5 & 6 & Clean water \\
\hline Hydrocarbons & 10 & 10 & 19 & 188 & 2 & 260 & $10^{-2 *}$ \\
$\mathrm{CO}_{2}$ & $10^{4}$ & $10^{3}$ & 1340 & 1200 & 700 & 1400 & $\mathrm{~N} / \mathrm{A}$ \\
$\mathrm{AT}$ & $<0.5$ & $<0.5$ & 22 & 12.5 & 10 & 30 & $\mathrm{~N} / \mathrm{A}$ \\
$\mathrm{CAT}$ & 550 & 625 & 123 & 147.5 & 122.5 & 165 & $50^{*}$ \\
$\mathrm{Cl}^{-}$ & 2492.1 & 2279.1 & 3227.6 & 3582.6 & $>24000$ & 3339.1 & $250^{* * * *}$ \\
$\mathrm{Total}^{*}$ hardness & 5000 & 5500 & 5280 & 4660 & 5000 & 4860 & $50^{*}$ \\
$\mathrm{PO}_{4}{ }^{-3}$ & 0.010 & 0.014 & $<0.02$ & $<0.02$ & $<0.02$ & $<0.02$ & Total $(0.64)$ \\
$\mathrm{pH}$ & 8.7 & 8.7 & 8.5 & 8.8 & 8.0 & 8.9 & $6.5-8.5^{*}$ \\
$\mathrm{~T} / \mathrm{C}$ & 28 & 28 & 26 & 28 & 26 & 28 & $25^{*}$ \\
$\mathrm{Conductivity}$ & $>10^{4}$ & $>10^{4}$ & $>10^{4}$ & $>10^{4}$ & $>10^{4}$ & $>10^{4}$ & $180-1000^{*}\left(20^{\circ} \mathrm{C}\right)$ \\
$\left(\mu \mathrm{S} . \mathrm{cm}^{-1}\right)$ & 4.24 & 6.72 & 5.36 & 8.4 & 4.5 & 9.6 & $\mathrm{~N} / \mathrm{A}$ \\
$\mathrm{COD}$ & & & &
\end{tabular}

*: Ref. [11], **: World Health Organization, N/A: Not available

\section{Methods of Analysis}

\section{Gravimetric Method}

This method can be simply done by evaporation of the extraction solvent and the residue weighing, by taking into account the abiotic (evaporation process) loss estimated in the marked sterile phials. This technique was often employed and presents an advantage due to its reproducibility and very easiness to perform. Fusey et al. [4-6] have shown that this technique is truly reliable.

For the extraction from the soil, the technique was modified; according to this technique we could determine the quantity of hydrocarbons (ppm) present into the sample to be analyzed. The principle of the method consists of the following points:

(1) Pour a known volume $(100 \mathrm{ml})$ of the sample to be analyzed into a phial.

(2) Add few drops of methyl orange and $0.2 \mathrm{ml}$ of $50 \% \mathrm{HCl}$ in order to acidify the sample.

(3) Add chloroform (best solvent for extraction of organic phases) to a half of the sample volume.

(4) Strongly agitate the phial with letting the gas escaping from it and then let the whole decant for a sufficient time. We can see the appearance of two phases, we take of the upper phase, then filtrate this latter with a paper filter containing sodium anhydride $\mathrm{Na}_{2} \mathrm{SO}_{4}$ in order to eliminate all traces of humidity.

The solvent containing the organic phase is recuperated in a beaker previously weighed, and then we place it into a stove until total evaporation occurs and then weighs the final sample, the quantity obtained of the residue is found through the formula:

$$
\text { Quantity }(\mathrm{ppm})=\frac{W_{f-W_{i}}}{V_{S}}
$$

$W_{\mathrm{f}}$ is the final weigh of the sample, $W_{\mathrm{i}}$ is the initial weigh of the sample and $V_{\mathrm{S}}$ is the volume of the sample, results are presented in Table 1.

\section{Chromatographic Method (CGP)}

The Chromatographic Method gaseous phase is a necessary method for the identification and the quantitative evaluation of sample components. It is widely used in petrochemical industry. This particular technique of chromatography consists of dragging volatile products trough a long capillary column. The column contains a stand (Silica for example) imbued into a liquid (silicone, glycol of polyethylene, etc...) as a stationary phase. The dragging gas is nitrogen, helium, or hydrogen with a debit of 1 to $5 \mathrm{ml} / \mathrm{mn}$.

As shown by Braithwaite et al. [7], McNair et al. [8], the CGP at programmed temperature is an excellent solution to several problems during the separation procedure. We started the analysis at low temperatures in order to separate components with low ebullition points, and then we raised the column temperature progressively in order to accelerate the driving out of heavier substances. One must raise the temperature linearly and avoid the drift of the line of the chromatogram basis dragged along by the modification of the viscosity of the gas vector during the rising of the temperature. The limited charge of the column requires the use of very sensitive detectors. The flame ionization detectors (FID) are suitable for the case of hydrocarbons. The sensitivity of FID can considerably be higher by aligning the flame alternatively with the hydrogen and oxygen sample. As for the stationary phase it is related to the chromatograph temperature, the choice of this latter depends on the maximum temperature of the device used.

The chromatograph-type used in our work is a (CARLO ERBA Strumentazione LT programmer MOD 232, Electrometer MOD 180, Fractovap series 2350, chromojet integrator); a stainless capillary column of 50 
$\mathrm{m}$ length and $0.26 \mathrm{~mm}$ of diameter and the gas vector is nitrogen $\left(\mathrm{N}_{2}\right)$. The stationary phase: Squalane $\mathrm{C}_{30}$ with a maximum temperature of $150 C$, the pressure is 0.7 $\mathrm{kg} / \mathrm{cm}^{2}$, a flame ionization detector (FID); the injection quantity is of $0.8 \mu \mathrm{l}$. The injection chamber works with programmable temperatures, with an initial temperature $T^{0}=20^{\circ} \mathrm{C}$ for a time of 15 minutes, then an increase of an increment of $1.5^{\circ} \mathrm{C}$ every minute until it reaches the temperature of $60^{\circ} \mathrm{C}$, then a second increase of the order of $1.5^{\circ} \mathrm{C}$ every minute until the temperature reaches the value of $95^{\circ} \mathrm{C}$.

First of all we start with the handling of the solvent containing the organic substance of interest, this step can be realized on a micro column "SEP PAK WATER" which enables us to eliminate traces of organic contaminants with keeping solely hydrocarbons. The recuperated residue was then dissolved into hexane then injected with a syringe in the silica micro column compressed to a volume of $5 \mathrm{ml}$.

Three fractions are then diluted successively with a $40 \mathrm{ml}$ of hexane (fraction A), $20 \mathrm{ml}$ of chloroform (fraction B) and $15 \mathrm{ml}$ of methanol that enables us to recuperate constituents that are normally should be diluted by chloroform and are identical to constituents of fraction Azoulay et al. [9] have shown that this kind of dilution corresponds to a $96 \%$ to $98 \%$ recovery of the initial organic material. The fraction A contains the totality of the saturated and aromatic hydrocarbons, this latter is injected into the GPC to be analyzed and keep it for about a time of 90 minutes. Figure 3 represents the variations of the hydrocarbons present into the area as a function of the location studied; it is clear that location 4 and 6 contain more hydrocarbons than the rest of the sites with a maximum value of $250 \mathrm{ppm}$.

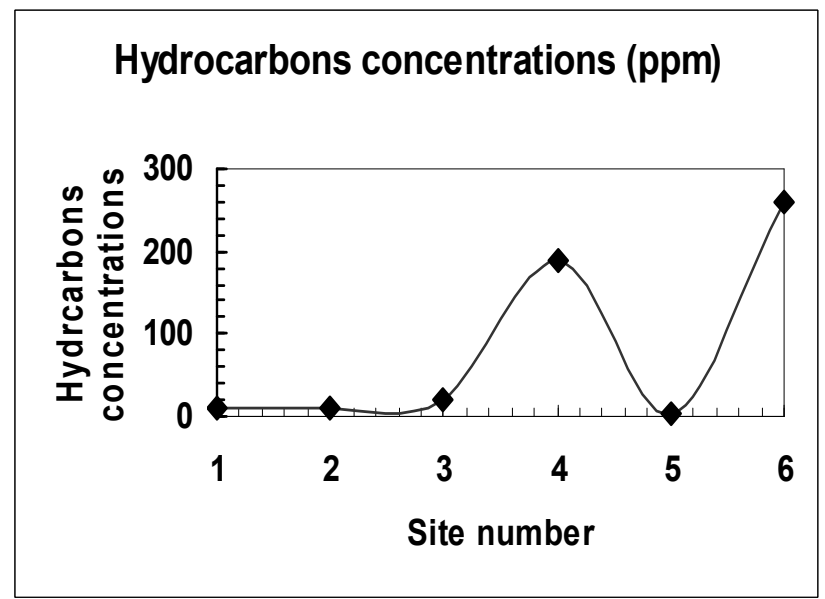

Figure 3: Variation of hydrocarbons concentration with the site number. The line-diamonds are the experimental data.

\section{Evaluation Method of $\mathrm{CO}_{2}$ Quantity}

This method is simple and quick to perform. In this analysis, $\mathrm{a} \mathrm{Na}_{2} \mathrm{CO}_{3}(0.045 M)$ solution was prepared with distilled, and a phenolphthalein solution by dissolving 1 $\mathrm{g}$ of phenolphthalein into $100 \mathrm{ml}$ of ethylic alcohol. The method consists of taking a sample of the non-organic phase, and adding few drops of phenolphthalein with $\mathrm{Na}_{2} \mathrm{CO}_{3}$ until we observe a change to a persisting pink.
To calculate the $\mathrm{CO}_{2}$ quantity we use the following formula:

$$
\mathrm{CO}_{2}(\mathrm{ppm})=\frac{A \times 1000}{B}
$$

Where $A$ is the volume in $\mathrm{ml}$ of $\mathrm{Na}_{2} \mathrm{CO}_{3}$ used in the titration and $B$ is the volume of the sample. Figure 4 shows the variations of the carbon dioxide present into the area as a function of the location studied. In the area close to site 4 , we find most of the concentration are located close to site 3 and 4 and in site number 6 , which is normal because $\mathrm{CO}_{2}$ concentrations increases with the increase of its source, which is in this case hydrocarbons.

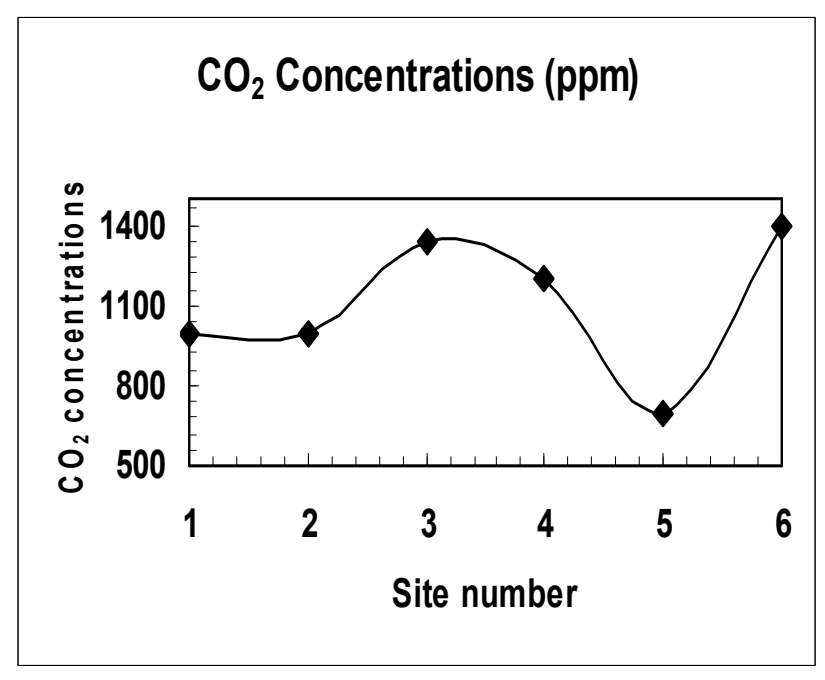

Figure 4: Variation of $\mathrm{CO}_{2}$ concentration with the site number. The line-diamonds are the experimental data.

\section{Determination of Alkalinity Rate}

The titration with a strong acid in the presence of phenolphthalein commonly is called $\mathrm{P}$ alkalinity (AT), and in the presence of methyl orange or $\mathrm{M}$ alkalinity (CAT). The titration (AT) corresponds to the sum of hydroxides and half of the carbonates, and the complete titration alkali meter corresponds to the sum of hydroxides, carbonates and bicarbonates.

In order to determine the (AT), we sample $100 \mathrm{ml}$ in the graduated cylinder to $300 \mathrm{ml}$, add 4 to 5 drops of phenolphthalein, and then perform titration with $\mathrm{H}_{2} \mathrm{SO}_{4}$ or $\mathrm{HCl}$ at $\mathrm{M} / 10$ until the disappearance of the red color. For the (CAT), we add to the preceding solution 4 to 5 drops of mixtures of indicators $(0.2 \mathrm{~g}$ of methyl red with $0.1 \mathrm{~g}$ of bromocresol green in $100 \mathrm{ml}$ of ethylic alcohol at $95 \%$ ), then perform titration with the same acid until a change to blue color from pink occurs. We calculate this quantity as follows: The (AT) expresses the quantity of $\mathrm{CaCO}_{3}$ in (ppm) $=A \times 50$, where $A$ is the volume of acid in $\mathrm{ml}$ at $M / 10$ used in the titration with the phenolphthalein, whereas the (CAT) expresses the quantity of $\mathrm{CaCO}_{3}=B \times 50$, where $B$ is the sum of acid volumes at $M / 10$ used in the two-step titration. The relationship established between the $\mathrm{M}$ alkalinity and the site number is shown in Figure 5, where site number 2 
contains more of hydroxides and half of the carbonates than the other site.

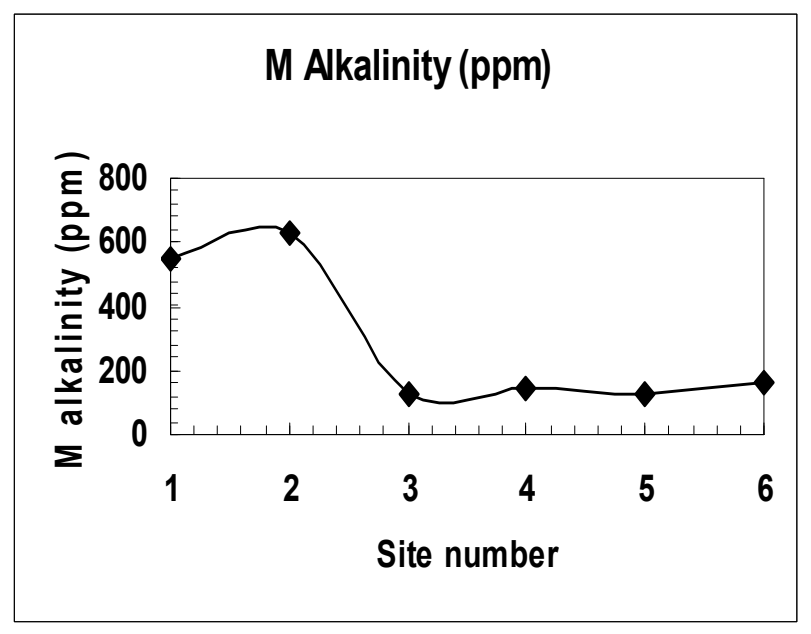

Figure 5: Variation of $M$ alkalinity with the site number. The line-diamonds are the experimental data.

\section{Total Hardness Determination}

The total hardness determination represents the soluble salts of alkaline-earth metal ions, particularly $\mathrm{Ca}^{+2}$ and $\mathrm{Mg}^{+2}$, which are found in several systems including inorganic, organic and biochemical alongside the other pollutants. The principle of this method consists in the titration with the ethylenediaminetetraacetic acid (EDTA) of $\mathrm{Ca}^{+2}$ and $\mathrm{Mg}^{+2}$ in the presence of Eriochrome black $\mathrm{T}$ as an indicator. This latter change color to red and turn to blue in the presence of $\mathrm{Ca}^{+2}$ and $\mathrm{Mg}^{+2}$ ions. The sample is made of $100 \mathrm{ml}$ in a $500 \mathrm{ml}$; we then add $10 \mathrm{ml}$ of standard solution (mixtures of several solutions of $\mathrm{NH}_{4} \mathrm{OH}$ at different densities), a $0.2 \mathrm{~g}$ indicator, and EDTA $(0.01 M)$. To calculate the amount of $\mathrm{CaCO}_{3}$, we use the following formula:

Total hardness of $\mathrm{CaCO}_{3}(\mathrm{ppm})=\frac{A F \times 1000}{V}$

where $A$ is the volume of EDTA used into the titration $(\mathrm{ml}), F$ is the volume of $\mathrm{CaCO}_{3}$ corresponding to a 1.0 $\mathrm{ml}$ of EDTA, and $V$ is the sample volume. Therefore, for a $V=100 \mathrm{ml}$ and EDTA at $0.1 \mathrm{M}$, the total hardness of $\mathrm{CaCO}_{3}$ expressed in ppm would be $=A \times 100$.

\section{Calcium and Magnesium Determination}

A $100 \mathrm{ml}$ of the sample was used into a graduated cylinder, added to it $2 \mathrm{ml}$ of $(1 M) \mathrm{NaOH}$ solution, $0.2 \mathrm{~g}$ of murexide indicator which in the presence of $\mathrm{Ca}^{+2}$ ions turns into purple color and change to violet when the quantity of ethylenediaminetetraacetic acid (EDTA) used into the titration is sufficient to Complexate the whole amount of $\mathrm{Ca}^{+2}$. To calculate the $\mathrm{Ca}^{+2}$ (ppm) total hardness of $\mathrm{CaCO}_{3}$, we use the following formula:

$A \times 10$ where $A$ is the volume of EDTA used into the titration (ml). As shown in Figure 6, the concentrations of calcium and magnesium reach its highest value at site 2 and its lowest value at site number 4 .

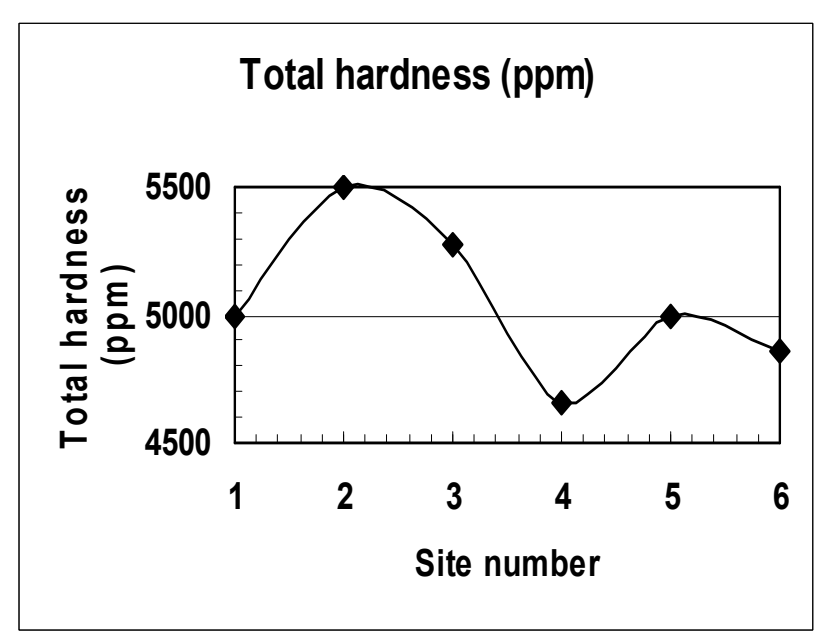

Figure 6: Variation of total hardness with the site number. The line-diamonds are the experimental data.

\section{Concentration of Chlorides}

The determination of chlorides is based on the amount of $\mathrm{AgNO}_{3}$ consumed; the principle consists of an excess titration of silver nitrate with sulfo-cyanide ammonium in the presence of ferric salt as an indicator. A $100 \mathrm{ml}$ of the sample is taken in a graduated cylinder, add a $5 \mathrm{ml}$ of $\mathrm{HNO}_{3}$ acid, then add an excess of a $0.02 \mathrm{M}$ $\mathrm{AgNO}_{3}$ and 5 to 6 drops of $40 \%$ ammoniacal iron indicator and finally perform a titration with a standard $0.02 M \mathrm{NH}_{4} \mathrm{SCNO}_{4} \mathrm{KSCN}_{4}$ until a persistent purple color. To calculate the chloride concentrations we use the following formula:

$\mathrm{Cl}(\mathrm{mg} / \mathrm{L})=\left(V-V_{1}\right) \times 7.1$

where $V$ is the volume of a $0.02 \mathrm{MAgNO}_{3}$ and $V_{1}$ is the volume of a $0.02 \mathrm{M} \mathrm{KSCN}$.

\section{Concentration of Phosphates}

A $100 \mathrm{ml}$ of the sample is taken in a graduated cylinder, add a $1 \mathrm{ml}$ of a $15 \% \mathrm{HCl}$ acid, then add $2 \mathrm{ml}$ ammonium molybdate, $2 \mathrm{ml}$ of 4.sulfonic.2.naphtol.1.amine acid (SNA), in the mean time, we prepared a white, and after few minutes we pass the sample through a spectrophotometer and read the wavelength that is equal to $650 \mathrm{~nm}$ and finally we determine the quantity of $\mathrm{PO}_{4}$ expressed in ppm as:

Absorbance x 6.82

\section{Concentration of Organic Substances}

This method, commonly called the Chemical Oxygen Demand (COD), can be obtained by the oxidation with the potassium permanganate. In order to 
realize this test, we take $100 \mathrm{ml}$ of the sample to which we add $10 \mathrm{ml}$ of a $20 \%$

$\mathrm{H}_{2} \mathrm{SO}_{4}$ and a $10 \mathrm{ml}$ of a $0.01 M \mathrm{KMNO}_{4}$, heat the whole in a manner to keep the solution color after ebullition, we then neutralize with oxalic acid until the discoloration of the solution color, then perform a titration with $\mathrm{KMNO}_{4}$ until the appearance of a persistent purple color. To calculate the Concentration of KMNO4 we use the following formula:

$$
\left[\mathrm{KMNO}_{4}\right](\mathrm{ppm})=\frac{\left(a F_{0}-b F_{1}\right) T}{V} \times 1000
$$

where $a$ is the total volume of $\mathrm{KMNO}_{4}$ at $0.01 M, F_{0}$ the correction factor of $\mathrm{KMNO}_{4}$ solution, $b$ volume of oxalic acid, $F_{1}$ the correction factor of oxalic acid solution, $T$ is the weight $(\mathrm{mg})$ of $\mathrm{KMNO}_{4}$ into $1 \mathrm{ml}$ of a $0.01 \mathrm{M}$ of $\mathrm{KMNO}_{4}=0.316$, and $V$ is the sample volume. The results of this analysis are presented in

Figure 7 which shows a three maxima in sites 2, 4 and 6 with a value as high as almost $10 \mathrm{ppm}$ and two minima in site 1,3 and 5 with a value as low as 4 ppm.

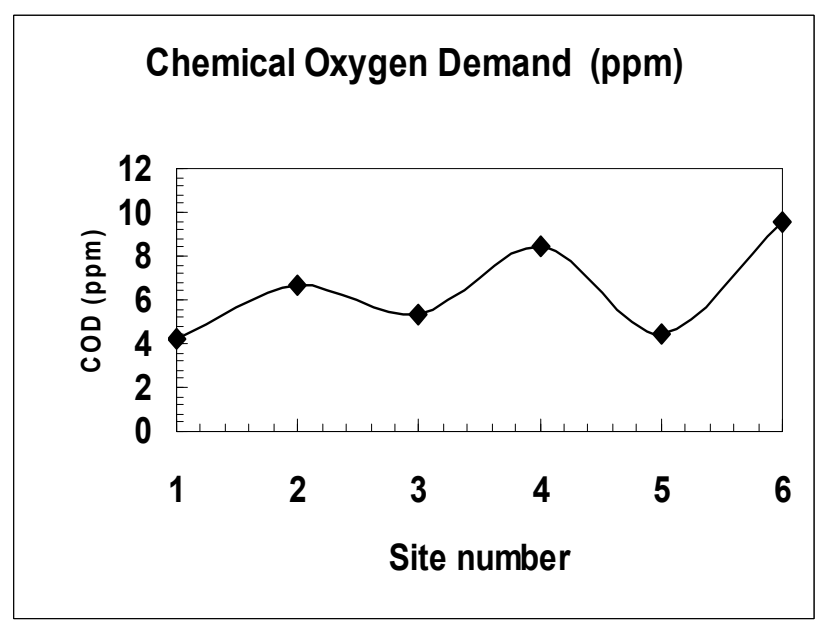

Figure 7: Variation of COD with the site number. The line-diamonds are the experimental data.

\section{Results and Discussion}

All the subsequent experimental results are presented in Table 1. We have included some data from clean water; we notice that most the concentrations of different chemicals found in our experiment in the six sites are well above the tolerated values as shown for clean water. The chemical analyses performed at different sites of the Skikda bay due to the petrochemical complex dumping show the great contamination of seawater compared to uncontaminated water. This work is a part of a global research work that included the microbiological analyses
[9] of different samples taken from different sites of the Skikda bay and close to the industrial dumping of its refinery. It has also shown different results that revealed contamination effect of the marine environment. We should also add that the Algerian Government has an ambitious program for water desalination of seawater due to drought, The results we found reveals a fact that the process purification of water would cost more money than expected, that is, seawater, not only it has to be desalted but also has to be purified from the excess of the above chemicals due to pollutions. Furthermore, the pollutants are not selected but are the ones we discovered in the area by using the above analyses.

\section{References}

1. Braga, C. E.: Diagnostico das Condiçoes Hidrogeologicas da Area Industrial Activa da Petroflex. S. A. Internal Report, Petroflex Ind. e. Com. S. A., 2001, 1-78.

2. Andrade, M. L. ; Reyzabal, M. L. ; Marcet, P. ; Montero, J. M. : Industrial Impact on Marsh Soils at the Bahia Blanca Ria. J. Envir. Quality, 2001, 31, 532-538.

3. Cardoso da Silva, Jr., G. ; Carlos, E.; de Carvalho Lange, I.: Hydrogeology of study of mangrove area around Guanabara bay, Rio de Janeiro, Brazil, Unuaro do Instito de Geociencias, UFRJ, 2003, 26, 92-100.

4. Fusey, P.; Oudot, J.: Note sur l'accélération de la biodégradation d'un pétrole brut par des bactéries. Mater. U. Organ., 1973, 8, 158-163.

5. Fusey, P.; Oudot, J.: Comparaison de deux méthodes d'évaluation de la biodégradation des hydrocarbures in vitro. Mater. U. Organ., 1976, 4, 241-251.

6. Fusey, P.; Lampin, M. F.; Oudot, J.: Recherche sur l'élimination des hydrocarbures par voie biologique. Mater. U. Organ., 1981, 2, 109-147.

7. Braithwaite, A.; Smith, F. J.: Chromatographic methods, $4^{\text {th }}$ ed. London, Chapman and Hall, 1985.

8. McNair, H. M.; Bonelli, E. J.: Basic gas chromatography, Walnut Creek, Calif.: Varian Aerograph, 1978.

9. Azoulay, E.; Colin, M.; Dubreuil, J.; Dou, H.; Mille, G. ; Giusti, G. : Relationship between hydrocarbons and bacterial activity in Mediterranean sédiments, $2^{\text {eme }}$ Colloque de microbiologie marine, 1982, 13, 119-142.

10. Boutefnouchet, N.; Bouzerna, N.: Biodegradation of Hydrocarbon by micro-organism, to be submitted to 18 ICCE, 4-8 August 2004, Istanbul, Turkey..

11. Directive du Conseil du 15 Juillet 1980, Relative à la qualité des eaux destinées à la consommation humaine $\mathrm{N}^{\circ}$ 80/779/CEE. 